\title{
Renewed tectonic extrusion of high-grade metamorphic rocks in the MCT footwall since Late Miocene (Sutlej Valley, India)
}

\author{
Vincent Baudraz †*, J ean-Claude Vannay†, Elizabeth Catlosł, Mike Cosca†, and Torsten Vennemann† \\ † Institut de Minéralogie et Géochimie, Université de Lausanne, CH-1015 Lausanne, SWITZERLAND \\ ¥ School of Geology, Oklahoma State University, Stillwater, OK, 74078, USA \\ *To whom correspondence should be addressed.E-mail: vincent.baudraz@img.unil.ch
}

The metamorphic crystalline core of the Himalaya is classically considered to be composed of a single tectonic unit, the High Himalayan Crystalline Sequence (HHCS), thrusted during Early Miocene over the low-grade sediments of the Lesser Himalaya along the Main Central Thrust (MCT). However, recent geochronological data from the MCT footwall (e.g., Catlos et al. 2002) indicate high-temperature protracted tectono-thermal activity up to Pliocene in the frontal part of the orogen, from Eastern Nepal to Garhwal (India). Further to the west, in the Sutlej Valley area (Himachal Pradesh, India), the metamorphic crystalline core is composed of two lithotectonic units, the High Himalayan Crystalline Sequence and the Lesser Himalayan Crystalline Sequence (LHCS). The latter crops out within a largescale antiformal tectonic window called the Larji-Kullu-Rampur Window. Both units show inverted metamorphic field gradients. New oxygen isotope thermometry combined with multiple equilibrium thermobarometry constrains the temperature and pressure field gradients for the LHCS. The $2.5 \mathrm{~km}$ thick, mylonitic schists forming the lowermost part of the unit show inverted temperature and pressure profiles, increasing upsection from about $520^{\circ} \mathrm{C}$ at $6.0 \mathrm{kbars}$ to about $600^{\circ} \mathrm{C}$ at 8.6 kbars. These data, together with the ubiquitous top-to-the-south sense of shear indicators associated to the mylonitic deformation, suggest that the metamorphic isograds were passively sheared and inverted during the extrusion of the unit. Above the mylonitic zone of the LHCS, the temperature profile flattens at about 620 to $650{ }^{\circ} \mathrm{C}$, whereas the pressure shows a marked decrease from about 8.6 to 6.5 kbars. These data are consistent with two different scenarios:

1) After having reached a maximum burial depth of about $30 \mathrm{~km}$, the LHCS unit initially experienced a temperature increase during the beginning of its extrusion, as a consequence of the relaxation of the deflected isotherms. As a function of their position in the unit, mineral assemblages recorded conditions corresponding to different periods of the thrusting/extrusion history.

2) Peak metamorphic conditions were reached contemporaneously in the whole unit and peak isotherms were strongly inverted. Both pressure and temperature gradients were subsequently deformed by a heterogeneous simple shear flow such as proposed in the channel flow model by Grujic et al. (1996). A combination of the two proposed scenarios is conceivable as they are not mutually exclusive.
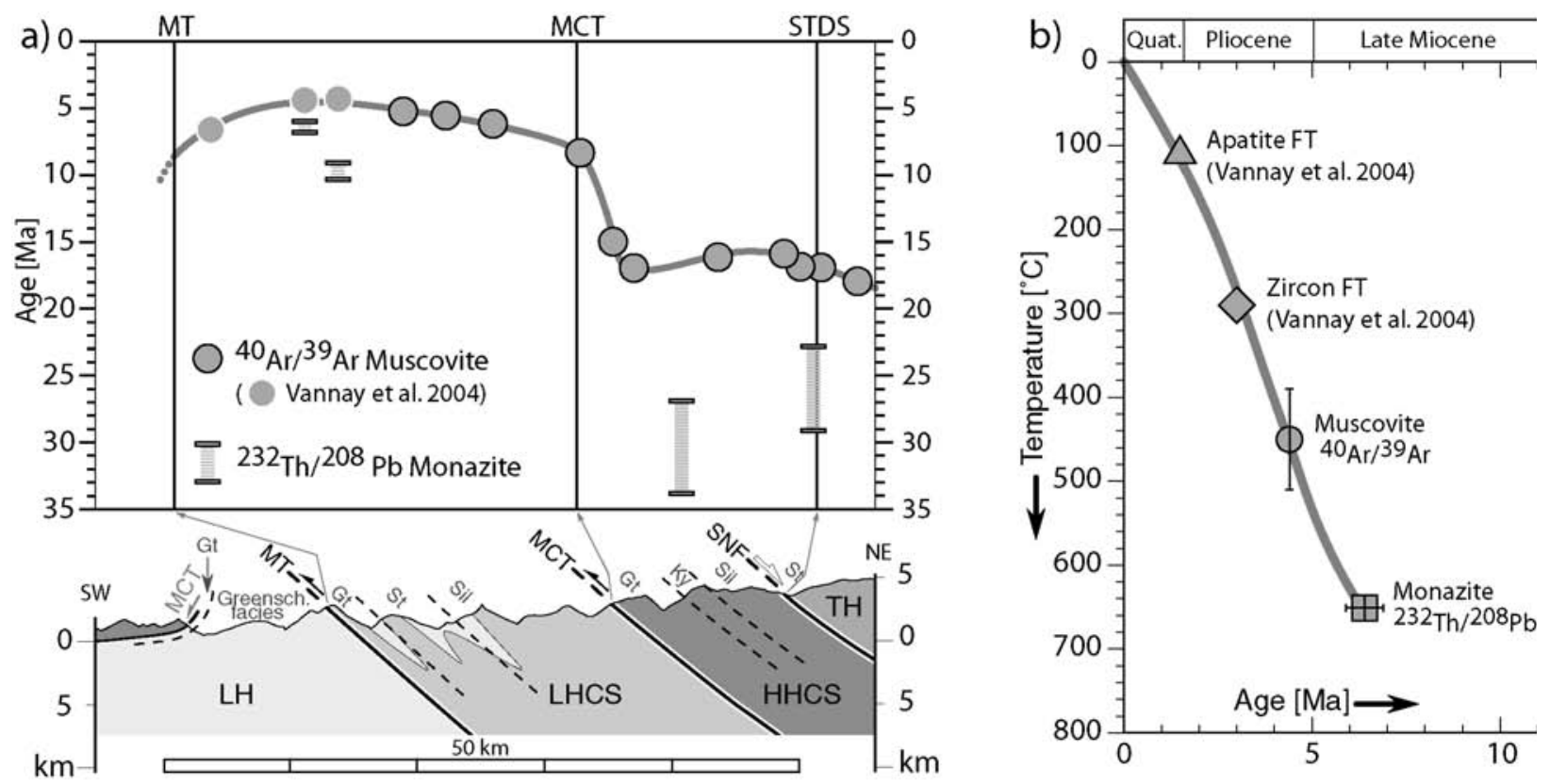

FIGURE 1. (a) Monazite crystallization ages and muscovite cooling ages from the Himalayan crystalline core in the Sutlej Valley, showing the distinct evolutions of both units. The monazite crystallization ages indicate a temperature peak after $6.4 \mathrm{Ma}$ in the LHCS and are in agreement with a temperature peak after $\sim 23 \mathrm{Ma}$ in the HHCS. (b) Cooling history of the LHCS unit, characterized by an average cooling rate of about $100^{\circ} \mathrm{C} / \mathrm{Ma}$, which corresponds to an extrusion rate of about $8 \mathrm{~mm} /$ year along the Munsiari Thrust. 
In situ $\mathrm{Th}-\mathrm{Pb}$ monazite ages from both units constrain the timing of the kinematic evolution of the Himalayan crystalline core. In the HHCS unit, multiple spot analyses from individual matrix monazite grains yielded ages ranging from $\sim 34$ to $\sim 23 \mathrm{Ma}$. These ages are interpreted as representing episodic growth during prograde metamorphism. It is unlikely that the grains suffered any $\mathrm{Pb}$ loss because of the very low $\mathrm{Pb}$ diffusivities in monazites (Cherniak et al. 2003), their P-T-path, and their size. In the lower part of the underlying LHCS, monazite crystals included in garnet have an age of $9.8 \pm 0.3 \mathrm{Ma}(\mathrm{MSWD}=0.4$ ), whereas a younger age of $6.4 \pm 0.5 \mathrm{Ma}$ has been measured for a crystal included in staurolite. These ages are interpreted as crystallization ages related to prograde metamorphism. Matrix monazite grains from the upper orthogneissic part of the LHCS, whose granitic protolith has an age of $1.84 \mathrm{Ga}$ (Miller et al. 2000), yielded variable ages ranging from $\sim 1090$ to $11 \mathrm{Ma}$. These ages are interpreted as mixed ages of inherited magmatic cores and metamorphic growth domains.

The new thermobarometric and geochronological data, together with systematic ${ }^{40} \mathrm{Ar} /{ }^{39} \mathrm{Ar}$ muscovite cooling ages across both units, allow us to reconstruct the tectono-thermal evolution of the active Himalayan front since the Eocene. In contrast to the HHCS that experienced Early Miocene peak metamorphic conditions followed by Early to Middle Miocene rapid exhumation along the MCT, the LHCS underwent Late Miocene peak metamorphic conditions followed by rapid exhumation along the Munsiari Thrust. The LHCS testifies to renewed and still active tectonic extrusion of high-grade metamorphic rocks, linked to on-going prograding deformation in the frontal parts of the Himalayan orogen.

\section{References}

Catlos E, TM Harrison, CE Manning, M Grove, SM Rai, MS Hubbard and BN Upreti. 2002. Records of the evolution of the Himalayan orogen from in situ $\mathrm{Th}-\mathrm{Pb}$ ion microprobe dating of monazite: Eastern Nepal and western Garhwal. J Asian Earth Sci 20(5): 459-79

Cherniak DJ, EB Watson, M Grove and TM Harrison. 2003. Pb diffusion in monazite: A combined RBS/SIMS study. Geoch et Cosmoch Act 68(4): 829-40

Grujic D, M Casey, C Davidson, LS Hollister, R Kundig, T Pavlis, and S Schmid . 1996. Ductile extrusion of the Higher Himalayan Crystalline in Bhutan: Evidence from quartz microfabrics. Tectonophysics 260(1): 21-43

Miller C, U Klötzli, W Frank, M Thöni, and B Grasemann. 2000 Proterozoic crustal evolution in the NW Himalaya (India) as recorded by circa 1.80 Ga mafic and 1.84 Ga granitic magmatism. Precambrian Res 103: 191-206 